\title{
Employing the Subsequent Four Years of the Libyan Education Reform Strategy: Administrations and Contributors
}

\author{
Dr. Ageila Ali Elabbar* \\ Academic Attaché at the Embassy of Libya, Washington DC \\ Original position: Staff Member at the Faculty of Education-University of Benghazi \\ *Corresponding author: Ageila.Elabbar@uob.edu.ly \\ Received November 17, 2018; Revised December 25, 2018; Accepted January 06, 2019
}

\begin{abstract}
This paper is the third continuation of the previously published paper "National Libyan Public Education Reform: Entire Transformative Strategies, 2020-2026" (November 2017), which proposes a complete framework for reforming Libyan public education and reflects on the difficulties that educators and learners have faced due to existing confusing conditions. It divides the entire reform plan into six years of gradual reform actions to overcome their complications; these complications stem from the discouraged forms of education, changeable curricula, bureaucratic schools and university administrations, the conservative community, and uncertain education strategies. Another factor is the way that learners acquire information (that is, their learning styles). In addition, upheavals all over Libya have affected the overall stability of education in Libya and led to there being two ministries of education (East and West Libya). Thus, six years of gradual reform stages were proposed so that a new generation of students would start with pre-kindergarten in the academic year 2026 or the equivalent. This paper also is subsequent to the prior published paper (16 May 2018) on the same reverence project, "Contextualizing the First Two Years of the Libyan Education Reform Proposed Strategies (2020-2026): Targeted Candidates and Reflective Activities," which explains in depth the suggested Phase I of the first two years (2020-2022) of the proposal for reforming Libyan education (2020-2026 or equivalent years). The purpose of this paper is to explain in depth the suggested subsequent four years (2022-2026 or equivalent years) of the proposed strategy of a six-year reform and come out with clearly constructed strategy without conflicting laws or regulations in the country.
\end{abstract}

Keywords: The second four years of actions, teachers' colleges, HQs, inspectors, Seiner teachers, curriculum designers, teachers' TV, MOE-database, role of social workers, expected new generation, new schools' structures and budgets

Cite This Article: Dr. Ageila Ali Elabbar, "Employing the Subsequent Four Years of the Libyan Education Reform Strategy: Administrations and Contributors." American Journal of Educational Research, vol. 7, no. 1 (2019): 12-18. doi: 10.12691/education-7-1-3.

\section{Emphasis on the Demonstrated Problem}

As explained, frequent studies in various sectors of education have focused on areas associated with teachers and teaching practices. These areas are teachers' knowledge, classroom interpretations, teachers' beliefs on teaching, cultural situations, and how these areas connect to each other theoretically. Wilson (1999) shows that teaching is a practical activity; to be a teacher, one needs to be very practical. Teachers also must find ways of using theory in the practice of teaching. This means that they must act within a community of other teachers; people do not learn in isolation, but as active members of society. What people learn and how they make sense of that knowledge depends on where and when they are learning, that is, the social context (172).
Elabbar [1] points out that the "Libyan English teachers learned to be Libyan teachers in a particular social context, using a particular kind of knowledge at a particular time, therefore their practices are socially constructed." The practices of Libyan educators have been constructed from their cultural background, their views on learning and teaching, and the kind of education they have received. Libyan educators are products of the way learning has been managed in the school or university context. These problems are exacerbated by top-down personal management and control; managers tend to consider all teachers qualified to teach any subject without specific trained. This managerial expectation puts pressure on teachers to perform without providing the necessary training or professional development support (14-16).

Therefore, these four years of transformational actions are concerned with gradual policy reform, professional development, structural aims to put into practice the project's main goals, and the anticipated results of Phase 1 . 
An additional aim is to include contributors from schools, vocational sectors, and higher education to unify clear attitudes toward the change. The results of several studies $[1,2,3,4,5]$ have uncovered significant difficulties and deep complications influencing Libyan education. Most of these complications result from the following facts:

\subsection{Education Policy Impairment: Schools and Universities}

The Libyan Education Authority $(1995,109)$ shows that the Libyan government provides policy statements detailing the aims of the school; for example, the "curriculum must cover all the activities in a school designed to promote the moral, cultural, intellectual and physical development of students, and must prepare them for the opportunities, responsibilities and experiences of life and society." However, El-Hawat (2006, 215) and Elabbar [2] explain that the school/university education systems are administrated by directors who apply whatever policy they personally feel is most suitable; this point has caused differences between schools, universities, and even faculties. Vandewall (2006) claims that "while educational development is still a priority for the government, the educational programmes in Libya suffer from limited and changeable curricula, a lack of qualified teachers, and a strong tendency to learn by memorisation rather than by reasoning, a characteristic of Arab education in general. Nonetheless, education is already free at all levels, and students receive a substantial salary" (40-42).

Also, the law in force (parliament decree ) in the state of Libya (18-2010 verse 2) clearly enables the Ministry of Education to take all possible actions toward development, reform, or support of professional development among all education sectors. However, all these regulations did not end up applying in terms of conditions in reality:

- Libyan beliefs and the culture of learning have strong consequences on the educational process.

- Many teachers may find it hard to apply different ideas, methods, and methodologies to their teaching; some of them simply attempt to teach by the same methods they learned from their Libyan teachers.

- The age and gender of teachers (OGT and NGT) affects the academic collaboration among them, as teachers face difficulties of age and gender, which influence to a certain extent their professional relationships with each other.

- Lack of knowledge and skills development inside schools and public universities have an impact on teachers' knowledge, how they perform while teaching, and their choices of teaching methods.

- Old and existing top-down approaches from the government, the Ministry of Education, and schools or universities may affect the inspiration that teachers exhibit for development or professional activities.

Latiwish [6] also highlights that the Committee of Higher Education (now called the Ministry of Education) provides a list of normal policies for universities, such as the start and end dates of academic years, faculty entrance scores, and the authorization of university heads and deans to other positions of academic managements (25). El-Hawat (2006) shows that this method of administration has increased the gap between schools, departments, faculties, and universities. Some faculty deans try to apply their own perspectives and beliefs of managing to their faculties, such as choosing department heads for personal or social reasons. Also, some heads of departments or administrators require their teachers to follow their perspectives on selecting materials, methods of teaching, and even managing exams (382).

- Poor facilities and resources within the whole education sector have an impact on teaching and learning processes.

- Having to instruct large numbers of students affects learning and teacher performance.

Therefore-and as the previous phase suggests - key contributors from the Ministry of Education and administrators from the entire Libyan educational system should put into practice the targets of the whole project through connecting the participants of all six years to track reform procedures.

\section{Literature Review}

\subsection{The Second Two Years, 2022-2024 or Equivalent Years}

The last published paper [5] contextualizes the first two years of the suggested six years of the reform strategy. These two years of transformational and gradual change of policy aim to put into practice the project's main goals in addition to the anticipated results of Phase 1. They also aim to widely include contributors from schools, vocational sectors, and higher education to unify clear attitudes toward change. Elabbar [5] also clarifies that all participants of the suggested Phase 1 should be invited to take a strong part in the second two years of developmental activities. Those officials invited to take part in Phase 1 are the following:

1. Government and parliament education policy makers (Education planers);

2. Ministry of Planning's officials in charge of preparing education budgets and polices;

3. Minister office managements, deputy minister managements, and the Ministry of Education consultancies;

4. County administrations and developments directors;

5. Education developers, curriculum creators, and teachers' trainers;

6. Ministry of Education research and training center executives;

7. Ministry of Education legal administrators;

8. Ministry of Education general exams executives;

9. Deans of universities and faculties of educations;

10. Senior inspectors and their TAs; and

11. Key people (decision makers) from the Ministry of Education, government, and parliaments in charge of education management in Libya (169).

The main goal of involving such officials in this four-year stage is to ensure implementation of the main goals of the reform project for 2020-2026. Also, it will facilitate the interaction with the four years of contributors to join the efforts of the targeted continuing professional development strategies (CPDS). 


\subsection{Continuing Professional Development (CPD) Brief Summary}

CPD can be seen as offering a systematic way of improving and developing educators' knowledge, perspectives, beliefs, and skills during their lifelong careers as educators. The Institute of Professional Development [7] defines CPD as combinations of approaches, ideas, concepts, and techniques that help teachers manage their own learning and development (20). Rodrigues [8] writes that "CPD is any process or activity that provides added value to the capability of the professional through the increase in knowledge, skills and personal qualities necessary for the appropriate execution of professional and technical duties, often termed competence" (11). Bell et al. [9] states that teachers can "review, renew and extend their commitment as agents of change to the moral purposes of teaching; and through this they acquire and develop critically the knowledge, beliefs, skills and emotional intelligence important to excellent professional thinking, planning and practice with children, young people and colleagues throughout each phase of their teaching lives" (p.4-6).

Lange [10] also shows that it is a "process of continual intellectual, experiential and attitudinal growth of teachers," which is essential for maintaining and enhancing the quality of teachers and learning experiences (250). Rodrigues [11] explains that a teacher's CPD shifts to meet accountability and credibility demands, as it is planned to enhance teachers' self-confidence, overall competence, and language of teaching or pedagogical content knowledge by providing instruction on the fundamental themes and perceptions in teaching process (387-391). Kanu [12] also suggests that CPD serves longer-term goals and seeks to facilitate the development of teachers' understanding of teaching as well as understanding themselves as educators (499).

\subsubsection{Process of CPD: Schoolteachers}

The process of teachers' CPD may be anything that helps teachers develop their skills and teaching beliefs to improve their teaching performances. Rodrigues [8] shows that the aims of CPD from a second or foreign language development perspective can cover any of the following: the process of how second/foreign language development grows; learning how roles transform according to the kind of the learners being taught; reviewing theories and principles of foreign language teaching; determining learners' perceptions of classroom activities; developing an understanding of different styles and aspects of teaching; understanding the sorts of decision making that occur during foreign language lessons; and building awareness of instructional objectives to support teaching (5-6). Also, Rodrigues et al. [11] states that "teacher development is more involved with in-service teacher education. It relies more on teachers' personal experiences and background knowledge as the basis of the input content, and typical teacher development activities through their teaching career," as it includes "teacher study groups, practitioner research, or self-development activities" (390). Guskey (2009) reports on the strong relationship between teachers' CPD and their students' outcomes and practice (490). Similarly, Guskey [13] offers four models of professional development as vehicles for changing teaching practice, leading to improvements in student achievement and outcomes, and changes in teachers' beliefs and attitudes (382).

\subsubsection{CPD in Higher Education}

The role of CPD in the field of higher education is explained by McWilliams [14], who points out that the term "continuing professional development" is widely used across a range of occupational fields: "There is however, a lack of clarity and agreement about how it is defined, and some acceptance that the concept is 'neither innocent nor neutral"" (289). Deem et al. [15] states that within the context of higher education, professional development for academics occurs within a complex situation of changing national policy "directives," increasing demands on both institutions and academics themselves (116). Also, Blackmore and Blackwell [16] show that the CPD of academics can be seen as taking place within a complex "array of competing challenges and perspectives." The nature of the academic role and the responsibilities attributed to it are changing, along with the relationships to other roles both within and outside the institution (22). Dill (2005) claims that "[i]t is equally...[i]mportant for the continuance of the university as we know it that we look systematically and critically at our own professional behaviour, at our structures of university self-governance, at our processes for peer review and at our underlying academic beliefs" (178).

The Higher Education Academy [17] states that CPD can be seen as "systematic, on-going, self-directed learning. It is an approach or process which should be a normal part of how you plan and manage your whole working life." Clegg [18] argues that the "problem of CPD of professionals in higher education is that it operates around a series of unresolved tensions" and goes on to explain "fault lines in conceptualising." Clegg [18] also explains that there are two "dualisms" in respect of what is considered appropriate for the content and focus of CPD in higher education, which reflects characteristic influences on academic identity. These dualisms form the "research-teaching nexus and the tension between loyalties to the subject discipline and the organization" (37-38).

\subsubsection{Strategies for CPD}

Lo (2005) shows that "Professional Development should go beyond personal and individual reflections, for example, it can include exploration of new approaches and theories in language teaching" (140).

The UK's Department for Education and Science (DFES) [19] suggests that CPD strategies should suit the needs of policy makers and funding and university managers and increase teachers' pedagogic and knowledge skills. Also, CPD strategies should increase and progress teachers' individual performances and develop their teaching beliefs and abilities. It consequently involves much more than just training courses. However, while many things can be learned about teaching through self-observation and critical reflection, many cannot. These include subject matter knowledge, pedagogical expertise, and understanding of curricula (126-127). The Architects Accreditation Council of Australia (2009) writes that formal CPD activities "should be structured in 
a learning environment with structured learning outcomes or assessment" (1). They also assume that formal CPD activities should include faculty seminars, workshops, courses, conferences, and presentations, among other activities. Informal CPD activities should, however, consist of self-directed study of practice, such as reading technical magazines, making site visits, attending talks and presentations by peers, and participating in mentoring programs (3).

\subsubsection{Applications of CPD}

CPD management and organizations should consider several concepts. Bell and Gilbert [9] determine three: the personal concept, the occupational concept, and the social concept. The personal concept covers teachers' values, attitudes, beliefs, and motivations. The occupational concept encourages a connection between theory and practice in addition to the essential focus on academic stimulation and professional relevance. The social concept encourages the relationship between individuals and groups (159-160).

Clegg [18] also shows that to understand the influences on CPD at individual and institutional levels, it is essential to take account of these debates as well as the significantly diverse approaches that different academic disciplines take to CPD (42). Crawford (2009) points out that these differences can be seen as "evolving from epistemological sources with academics being positioned within many systems or communities, each of which may have different discourses, approaches to teaching and learning, understandings of CPD and priority." Besides the changes related to the meanings attributed to $\mathrm{CPD}$, there is also obvious difference in the appropriate form and approach to CPD activity. The core of the matter can be seen to pivot on whether CPD activity includes formal and informal approaches to learning in the workplace (165).

\section{Proposed Actions}

\subsection{Teachers Colleges (TCs)}

The reform's main aims need to consider how future teachers gain and develop their pedagogical content knowledge (PCK). TCs will also require having working classroom equipment, teaching aids, IT systems, modern laps, online library access, and well-trained educators who can apply the reform's main goals; to this aim, they (TC educators) should have taken part in Phase 1 (2020-2022 or equivalent years) preparations. As the preservice educators, teaching assistants should learn about student centers, decentralized forms of education, and getting the new student-teachers ready for the transformation. TCs syllabuses should also cover core materials, ground-up activities, app communication, and practical aspects; all preservice and student-teachers should get enough time to practice PCK before they take part in the reform arrangements.

These practices might take several methods or platforms, such as at schools' locations, laps, libraries, or short-terms external training facilities. TCs are a significant part in formulating teachers with clearly planned ideas of the change. In other words, TCs must play an important role in implementing the reform's main goals. TCs will have to work to adjust their syllabuses, teaching methods, and teaching aids and move from centralized to decentralized forms of education as well as administration.

\subsection{Ministry Training Centers (MTCs)}

MTCs must play an important role in collaboration with TCs in applying CPD reform models, such as national teacher training programs, action research, coaching, cascading, and transformative training to the suggested contributors. MTCs should also collaborate with international universities and research centers that have gone through a reform process. Correspondingly, MTCs must shore up the development process toward the involvement of the in-service teachers, inspectors, school headquarters, education administrators, and social workers to participate in contextualizing the transformation goals.

\subsection{Teachers' TV (TTV)}

This managed channel (both TV and internet) aims to help pre- and in-service educators keep up with fundamental development activities and track all preparation stages. Those teachers will then have excellent opportunities to watch all training sessions, recorded reform lectures, lesson plan activities, communicative learning manners, and teacher education; they will be able to see the importance of material design, action research, and transformative knowledge. Also, it will be further recommended to prepare an app (phone app) where all reform contributors track reform constrictions. This process will ensure an intensive look at the trajectory of the improvement.

\subsection{Curriculum Designers}

Those designers require intensive professional development regarding material development and adaptation to be able to achieve the following goals of the reform:

- Making a core curriculum for the new generation of pupils who will start in 2026-2027. This core curriculum would include reading, writing, math, science, technology, Islamic studies, English language, French language, and citizenship.

- Making a peripheral curriculum: history, music, arts, social studies, and physical education.

- Making gradual modifications for the current students to enable classroom interaction, shared work, and technology adoption.

- Giving spaces in the teachers' books to enable teachers to develop activities and use ground-up activities.

- Requiring the university syllabus to meet the reform preparations in terms of content knowledge, use of technology, and forging languages.

\subsection{Debates}

Debates and workshops must frequently occur within all levels of contributors and reform administrators to overcome unanticipated constraints that may happen during the reform journey. Also, these debates should be 
well administrated in terms of outcomes, bottom-up debates, and top-down debates to enable all contributors to increase their philosophies either through direct participations or through teachers' TV or apps.

\subsection{Role of Social Workers in the Change}

Social workers are significant in the change and should be extensively involved within all practical activities. As they will be required to further connect with the traditional Libyan teachers, parents, and students, they would be trained on preparing the families and students to accept the gradual change.

\section{Current Education Budget, Numbers, and Expectations}

According to the ministry's published report (2015), over the past 17 years, Libya has spent an annual budget of approximately 1.3 billion Libyan dinars (approximately US\$1 billion) for the Ministry of Education alone and without a clear developmental policy. This unplanned budget has led to confusion, as it was not used to build a strong base for approximately 1.4 million school learners (201000) in the vocational sector and approximately 435,000 university students. Nevertheless, Elabbar [2] explains that with a huge budget and a small population, most of the current classrooms consist of 45 to 50 students each. This number does not agree with the large number of assigned teachers (on documents only, 745,000), which means approximately one teacher for four students. Thus, part of this project's main aims is to use such a budget in the six-year reform plan. For example, Maghaib's (2017) statistical report based on the national ID system shows that by 2021, the entire Libyan population is expected to reach $6,785,839$, with an annual growth of 1.3 and fertility rate of 2.315. Thus, Libya will have approximately 581,458 new children aged between 0 and 4 years (68).

\section{Predicted Structure, Budget, and Policy}

This phase would come as a result of the two prior phases (Phases 1 and 2). It aims to prepare students who are suggested to start the academic year 2026-2027 (pre-k). Those learners are anticipated to be approximately 504,000 pre-k students. This phase also aims to implement the goals of this project, which are creating a modern learning environment and having well-equipped classrooms (no more than 20 students per class), well-trained teachers, and HQs; these goals can be achieved through a well-organized county system that applies the aims of this project as framework procedures. Therefore, the number of expected required new classrooms will be approximately 29,073. Maghaib (2017) anticipates the cost of a well-equipped classroom (according to US standards) to be approximately US\$60,000 per class, which means approximately 2,325,832,000 Libyan dinars (approximately US\$2.1 billion). This study also anticipates that the annual cost of each student, including administration, teachers, training, transportation, equipment, carting, and school supplies, is approximately 20,000 Libyan dinars (US\$17,500).

Thus, the total anticipated or required annual budget for the new reformed education with teaching and administration will be approximately US\$104, 6624, 4000, which is approximately 1.6 billion Libyan dinars every year, plus the cost of adding the required classrooms.

\section{Conclusion}

This framework proposal has aimed to open doors for key Libyan education figures to analyze ideas of reforming a complicated learning context. It considers the current position of Libyan educators, policy makers, and the difficulties they face because of having used an unstable system for more than 47 years. This proposal also considers different models of CPD, cultural reflection, current students, and economic thought based on the currently addressed budget in the state of Libya. Most of the suggested aims have been designed to be linked to or modified in the face of wider ideas of reform of the complex situation in Libya. Libya and Libyans deserve better educational development and collaboration to achieve anticipated reform and targeted outcomes.

\section{References}

[1] Elabbar. (2011). An investigation of influences affecting Libyan English as Foreign Language University Teachers (LEFLUTs), teaching approaches in the language classrooms phd thesis, university of Glasgow. UK.

[2] Elabbar. (2016). Libyan Political Conflict: Effects on Higher Education development. Scientific Research Journal (SCIRJ), Volume IV, Issue XII, December 20161 ISSN 2201-2796.

[3] Elabbar. (2013). Libyan English as a Foreign Language School Teachers' (LEFLSTs) Knowledge of Teaching: Action Research as Continuing Professional Development Model for Libyan School Teachers. IOSR Journal of Humanities and Social Science (IOS).

[4] Elabbar. (2017), "National Libyan Public Education Reform: Entire Transformative Strategies, 2020-2026.” American Journal of Educational Research, vol. 5, no. 6 (2017): 1044-1057.

[5] Elabbar. (2018). Contextualizing the First Two Years of the Libyan Education Reform Proposed Strategies (2020-2026): Targeted Candidates and Reflective Activities, American Journal of Educational Research, vol. 6, no. 6 (2018): 1269-1281.

[6] Latiwish, M. (2003). Teacher's training strategies. Benghazi: University of Garyounis Press.

[7] Institute of Professional Development (IPD). (2006). Uses of CPD From http://www.ipd.org/ [Accessed on 25 July 2017].

[8] Rodrigues, S. (2004). International perspective on teachers' professional development: Changes influenced by politic pedagogy and innovation. New York, NY: Nova Publishers.

[9] Bell, B. and J. Gilbert. (2001). Teacher development: a model from science education 4(6), 3-10.

[10] Lange, D. (1990). A blueprint for a teacher development programme. In J. C. Richards and D. Nunan (Eds.) Second language teacher education. Cambridge: Cambridge University Press, 245-268.

[11] Rodrigues, S. M. A. and P. Steel. (2005). Developing science and ICT pedagogical content knowledge: a model of containing professional developments, Edinburgh.

[12] Kanu, Y. (2005). Tensions and dilemmas of cross-cultural transfer of knowledge: post structural/ postcolonial reflections on an innovative teacher education in Pakistan. International Journal of Educational Development 25(4), 493-513.

[13] Guskey, T. R. (2002) Professional development and teacher change. Teachers and teaching Theory and practice 8(3/4), 381-391. 
[14] McWilliam, E. (2002) Against Professional Development. Educational Philosophy and Theory 34(3), 289-299.

[15] Deem, R., Hillyard, S. and M. Reed (2008) Knowledge, Higher Education, and the New Managerialism: The Changing Management of UK Universities, Oxford: Open University Press.

[16] Blackmore, P. and Blackwell, R. (2003). 'Academic roles and relationships' in R. Blackwell and P. Blackmore (Eds) Towards Strategic Staff Development in Higher Education, Berkshire: SRHE and Open University Press, 16-28.

[17] Higher Education Academy (HEA). (2006). The UK Professional Standards Framework for teaching and supporting learning in higher education. From www.heacademy.ac.uk

[18] Clegg, S. (2003) Problematizing Ourselves: Continuing Professional Development in Higher Education. International Journal for Academic Development 8(1/2), pp37-50.

[19] Department for Education and Employment (DFEE) (2000) Professional development: Support for teaching and learning. London: DFEE.

[20] Abell, S.K. (2008) Twenty years later: Does pedagogical content knowledge remain a useful idea? International Journal of Science Education 30(10), 1405-1416.

[21] Alberta Teachers' Association (ATA) (2000) Action research guide for Alberta teachers. From

$<\mathrm{http}: / /$ www.teachers.ab.ca/services/publications (accessed on 10july-2017).

[22] Ball, D.L., \& Bass, H. (2000). Interweaving content and pedagogy in teaching and learning to teach: Knowing and using mathematics. In J.Boaler (Ed.) Multiple Perspectives on Mathematics of Teaching and Learning. (pp. 83-104). Westport, Conn.: Ablex Publishing.

[23] Bates, T, Gough, B and P. Stammers. (1999). The role of central government and its agencies in the continuing Professional development of teachers: an evaluation of recent changes in its financing in England" Journal of In service education 25(2), 321-335.

[24] Baumfield, V., Hall, E. and K. Wall. (2008). Action research in the classroom. London: Sage.

[25] Bax, S. (2003). The end of CLT: a context approach to language teaching. ELT Journal 57(3), 278-87.

[26] Boreham, N. (2004). A Theory of collective competence: Challenging the neoliberal individualisation of performance at work. British Journal of Educational Studies 52, 20-35.

[27] Brien, O. (1998). An overview of the methodological approach of action research. American institute for research 2(4), 1-14.

[28] Burbank, M. D. and D. Kauchak. (2003). An alternative model for professional development: Investigations into effective collaboration. Teaching and Teacher Education 19, 499-522.

[29] Burns, A. (1996). Starting all over again: from teaching adults to teaching beginners. In D. Freeman and J. C. Richards (Eds.) Teacher learning in language teaching. Cambridge: Cambridge University Press, 122-135.

[30] Clare, J., White, J., Edwards, H. and van Loon, A. (2000). Learning outcomes and curriculum development in the major disciplines: Nursing. Australian Universities Teaching Committee. page 110-129.

[31] Clarke, D. and Hollingsworth, H. (2002). Elaborating a model of teacher professional growth. Teaching \& Teacher Education 18(8), 947-967.

[32] Cranton, P. (2006). Understanding and promoting transformative learning: A guide for educators of adults. San Francisco: JosseyBass.

[33] Curran, E., \& Murray, M. (2008). Transformative learning in teacher education: Building competencies and changing dispositions. Journal of Scholarship of Teaching and Learning, 8, 103-118.

[34] Day, C. (1999). Developing teachers: The challenges of lifelong learning. London: Falmer press.

[35] Denzin, N. K., and Y. S. Lincoln (Eds.). (2000). Handbook of qualitative research (2nd edition ed.) Thousand Oaks: Sage Publications.

[36] Department for Education and Science (DFES). (2004). National standards for head teachers, Annesley: DFES Publications.

[37] Desimone, L. M. (2009). Improving impact studies of teachers' professional development: toward better conceptualizations and measures. Educational Researcher 38, 181-199.
[38] Draper, J., O’Brien, J. and F. Christie. (2004). First Impressions: The new teacher induction arrangements in Scotland. Journal of In-service Education 28, 198-212.

[39] Feldman, A. (2002). Existential approaches to action research. Educational Action Research 10(1), 233-240.

[40] Fennema, E. and M. L. Franke. (1992). Teachers' knowledge and its impact. In D.A. Grouws (Ed.) Handbook of research on mathematics teaching and learning. New York: Macmillan, 147-164.

[41] Ferrance, E. (2000). Action research. Providence, RI: Northeast and Islands Regional Educational Laboratory at Brown University.

[42] Greenbank. (2003). Reflexivity and positionality. From www.strath.ac.uk/aer/materials/6furtherqualitativeresearchdesigna ndanalysis/unit1/reflexivityandpositionality. [Accessed on 13 August 2017].

[43] Greenwood, D.J. and M. Levin. (1998). Introduction to action research: social research for social change. Thousand Oaks, CA: Sage.

[44] Guskey, T. R. (2000). Evaluating professional development. Thousand Oaks, CA: Corwin Press, 64-65.

[45] Henderson, E. S. (1978). The evaluation of In-Service Teacher Training. London: Croom Helm.

[46] Hew, K. F. and Hara, N. (2007). Empirical study of motivation and barriers of teacher knowledge sharing. Educational Technology Research \& Development 55(6), 573-595.

[47] Hill, L. (2000). What does it take to change minds? Intellectual development of pre-service teachers. Journal of Teacher Education 51(1), 50-62.

[48] Hittleman, D. R. and A. J. Simon. (2006). Interpreting educational research. An introduction for Consumers of Research (4th Ed). Columbus, Ohio: Prentice Hall.

[49] Hoban, G. (2002). Teacher learning for educational change: A systems thinking approach. Buckingham: Open University Press.

[50] Hoban, G.F. (2002). Teacher learning for educational change. Buckingham: Open University Press.

[51] Holliday, A. (2005). Doing and writing qualitative research. London: Sage.

[52] Hudson. L. (2002). Holding complexity and searching for meaning: teaching as reflective practice. Journal of Curriculum Studies 1(33), 40-53.

[53] International Association of Universities (IAU). (2009). Structure of educational system: Admissions to higher education recognition of Foreign Credentials. From http://www.iauaiu.net/ [Accessed on 15 august 2017].

[54] Kennedy, A. (2005). Models of continuing professional development (CPD): a framework for analysis. Journal of InService Education 21(2), 233-252.

[55] Khalifa, S.M.G. (2002). The use of computers in the teaching of mathematics in Libyan primary. From http:/hdl.handle.net/ 10068/508910 [Accessed on 2 November 2017].

[56] Kharma, N. and A. Hajjaj. (1997). Errors in English among Arabic speakers. Beirut: Librairie du Liban.

[57] King, K. P. (2004). Both sides now: Examining transformative learning and professional development of educators. Innovative Higher Education 29(2), 155-174.

[58] Kirk, G., Beveridge, W. and I. Smith. (2003). Policy and practice in education: the chartered teacher. Edinburgh: Dunedin academic press.

[59] Korthagen, F., Loughran, J. and T. Russell. (2006). Developing fundamental principles for teacher education programs and practices. Teaching and Teacher Education 22(8), 10201041.

[60] Levin, M. and D. Greenwood. (2001). Pragmatic action research and the struggle to transform universities into learning communities. In P. Reason and H. Bradbury (Eds.) Handbook of Action Research: Participative Inquiry and Practice. London: Sage.

[61] Loucks-horsley, S., Newson, P.W., Love, N., E. and K. E. Stoles. (1998). Designing professional development for teachers of science and mathematics. One Thousand Oaks, CA: Corwin Press.

[62] Lunenberg, M., F. Korthagen and A. Swennen. (2007). The teacher educator as a role model. Teaching and Teacher Education 23(5), 586-601.

[63] McNiff, J., Lomax, P. and J. Whitehead. (1996). You and your action research project. London: Routledge. 
[64] Mezirow, J. A. (2000). Learning as transformation: Critical perspective on a theory in progress. San Francisco, CA: JosseyBass.

[65] Mills, G. E. (ed.). (2007). Action research. A guide for the teacher researcher. Ohio: Prentice Hall Columbus.

[66] Rajab, A. (2007). Student attitudes in the context of the curriculum in Libyan education in middle and high schools. Unpublished $\mathrm{PhD}$ Thesis, University of Glasgow.

[67] Reza Arabsheibani, G. and L. Manfor. (2007). Non-Linearities in Returns to Education in Libya. Education Economics 9(1), 134-145.

[68] Rhodes, C. and S. Beneicke. (2002). Coaching, Mentoring and Peer-networking: challenges for the management of teacher professional development in schools. Journal of In-service Education 28, 297-309.

[69] Richards, J. C. and T. S. C. Farrell. (2005). Professional development for language teachers. New York, NY: Cambridge University Press.
[70] Robinson-Pant, A. (2007). Cross Cultural Perspectives on Educational Research. Berkshire: Open University Press.

[71] Rogers, T. (2001) Language teaching methodology. From http://www.cal.org/resources/digest/rodgers.html [Accessed on 13 September 2017].

[72] Sabander, J. (1999). Language learning in large classes in Indonesia. Lancaster-Leeds Language Learning in Large Classes Research Project - project report no. 9. From http://opensigle.inist.fr/handle/10068/516519 [Accessed on 13 April 2017].

[73] Wenger, E. (2007). Communities of practice: A brief introduction. From http://www.ewenger.com/theory/ [Accessed on 14 July 2017].

[74] Widdowson, H. G. (1990) Aspects of language teaching. Oxford: Oxford University Press. 